\title{
THE RANGE AND DISTRIBUTION OF BLOOD PRESSURES IN NORMAL CHILDREN
}

\author{
CLINICAL APPLICATION OF STATISTICAL METHODS TO THE INTER- \\ PRETATION OF DEVIATION FROM THE NORMAL AVERAGE * \\ HAROLD K. FABER M.D., AND CHARLES A. JAMES, M.D. \\ SAN FRANCISCO
}

The usefulness of blood pressure determination as means of diagnosis has long suffered from the lack of suitable standards which would define accurately the limits of normal tension and of pathologic hypotension or hypertension. We are abundantly supplied with averages, but averages have, at best, an academic value unless they are supplemented by standards of normal deviation from the average. Particularly in pediatrics, the lack of such standards of deviation has resulted in the neglect of sphygmomanometry as having too little practical value. It has seemed to us that much useful information regarding the cardiovascular functions and disturbances of childhood might be obtainable once the desired normal standards were established, and it was in an effort provisionally to formulate such standards that the present study was undertaken.

Not only blood pressure statistics but nearly all medical statistics have been organized in such a way as to give averages only. In some instances, authors have attempted to furnish maximum and minimum values also, but, realizing the unreliability of absolute maximum and minimum findings, they have determined the average maximum and average minimum values, a method which may justly be criticized. In general, the range has been disregarded, not because it is not important to know but because it is very difficult satisfactorily to define.

GENERAL PRINCIPLES ${ }^{1}$

It has of course been realized that individual measurements, as of blood pressure, always deviate to some extent from the average and

* Received for publication Dec. 17, 1920.

* From the Department of Pediatrics, Stanford University Medical School.

1. For a discussion of the principles and application of the statistical methods we have employed, see Yule, ${ }^{2}$ Davenport ${ }^{3}$ or Rugg."

2. Yule, G. U.: An Introduction to the Theory of Statistics, Griffin \& Co., 1912.

3. Davenport, C. B.: Statistical Methods with Special Reference to Biological Variation, New York, John Wiley \& Sons. Inc., 1914.

4. Rugg, H. O.: Statistical Methods Applied to Education, Houghton Mifflin Co., 1917. 
that when we compare such individual measurements with the average in order to decide whether or not abnormality is present we must make allowances for normal deviation. Hence we are accustomed in practice to speak of a "normal range," within the limits of which all measurements must be regarded as normal, but it is noteworthy that no two clinicians can be found to agree on the exact limits. Nevertheless there is no difficulty, even on inspection, in classifying as normal those readings which are near the average, or as abnormal those which show extreme deviation from the average. Clearly, then, there is an intermediate zone in the range of pressures, between the certainly normal and the certainly abnormal where interpretation is in doubt and where our chief difficulties lie. In this zone, how are we to measure deviations in such a way as to discover their true significance? Kilgore ${ }^{5}$ in his illuminating paper, has recently called attention to the potential usefulness of the statistical method of frequency distribution for the solution of medical problems of this nature, and it is by this method that we have organized our material. An outline of the method will serve to make its applications 'clearer.

\section{THE METHOD OF FREQUENCY DISTRIBUTION}

If we take the blood pressures of a large series of presumptively normal individuals, we shall find that a majority occur at or near the average pressure of the whole group, and that at levels of pressure more distant from the average a smaller number of cases occur. If the distribution of such a series were plotted, the curve would approximate in form the mathematical probability or frequency curve, shown in Figure 1. The latter expresses not only the ideal distribution of a homogeneous series of normal data, but it can also be used to show the proportion of cases which will show any given deviation from the average, and also the chances that a given individual will show a given deviation from the average. Similarly, by clinical inference, it is clear that the nearer his pressure is to the average of all normal individuals, the greater are the chances that his pressure is normal ; and, conversely, the greater his deviation from the average, the greater the chances that his pressure is abnormal, and the smaller the chances that his pressure is normal. In the mathematical statistical system the proportions and chances referred to are determined by the use of a measure of deviation from the mean, or average, which is known as the standard deviation of Pearson. ${ }^{6}$ By dividing the devia-

5. Kilgore, E. S.: Relation of Quantitative Methods to the Advance of Medical Science, J. A. M. A. 75:86 (July 10) 1920.

6. The standard deviation is the square root of the arithmetic mean of the square of the deviations from the average of the distribution. It is designated by the Greek letter sigma $(\sigma)$. 


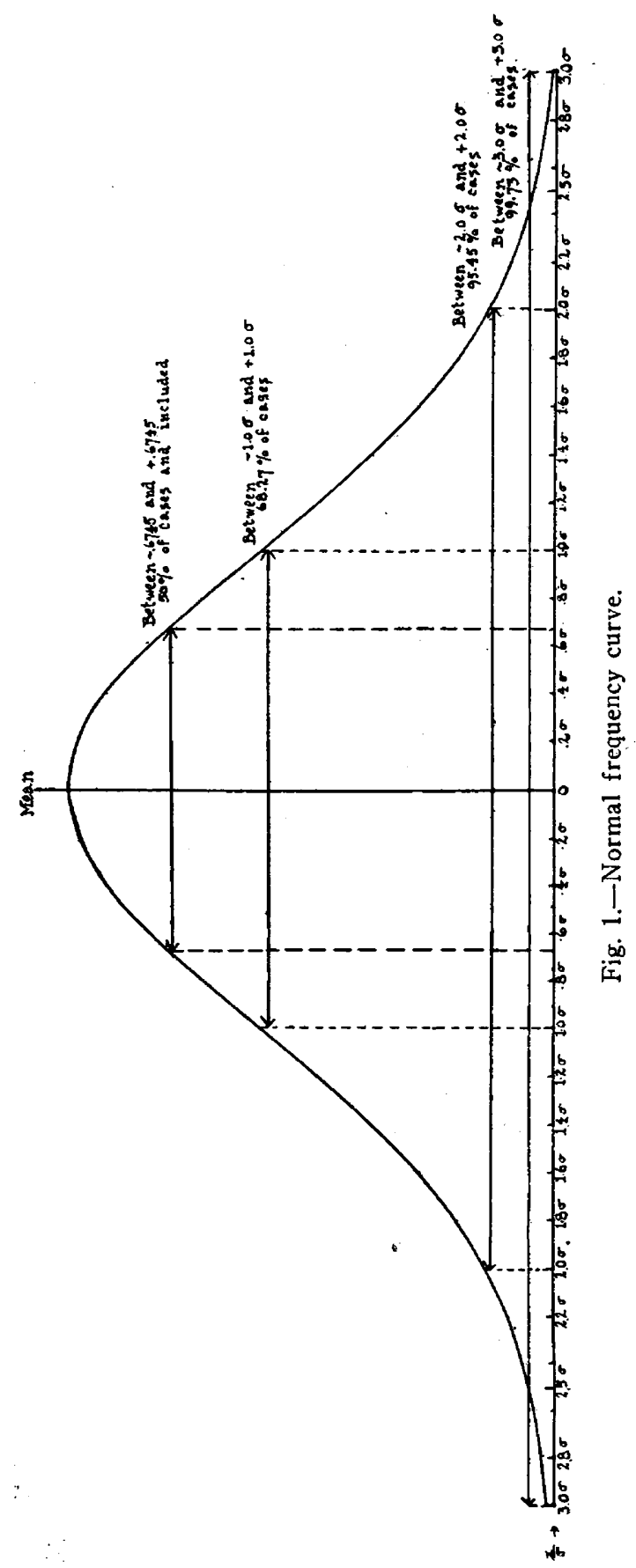

Downloaded From: http://archpedi.jamanetwork.com/ by a Southern Illinois University - Carbondale User on 06/04/2015 
tion of a given measurement from the average by the standard deviation, we obtain a quotient, to which we have applied the term "deviation index," having a definite relation to the normal, or ideal distribution, and showing the normal proportion of cases occurring at the given level. The deviation index would appear to have an important clinical value in defining the significance of individual variations from the average, and also in determining the normal and abnormal range. In order to obtain it in any given case, it is necessary only to know the corresponding average and standard deviation. The exact meaning of the deviation index is illustrated by the following tabulations:

In a series of normal cases ideally distributed,

49.86 per cent. will have a deviation index between $-3.0^{7}$ and 0

47.7 per cent. will have a deviation index between -2.0 and 0

34.1 per cent. will have a deviation index between -1.0 and 0

34.1 per cent. will have a deviation index between +1.0 and 0

47.1 per cent. will have a deviation index between +2.0 and 0

49.86 per cent. will have a deviation index between +3.0 and 0

and, conversely,

0.14 per cent will have a deviation index of less than -3.0

2.3 per cent. will have a deviation index of less than -2.0

34.1 per cent. will have a deviation index of less than -1.0

50.0 per cent. will have a deviation index of less than 0

50.0 per cent. will have a deviation index of more than 0

34.1 per cent. will have a deviation index of more than +1.0

2.3 per cent. will have a deviation index of more than +2.0

0.14 per cent. will have a deviation index of more than +3.0

hence, the chances that the index of a normal individual will be

less than -3.0 are 1 in 741 or 1 to 740
less than -2.0 are 1 in 44 or 1 to 43
less than -1.0 are 1 in 6.3 or 1 to 5.3
less than 0 are 1 in 2 or 1 to 1
more than 0 are 1 in 2 or 1 to 1
more than +1.0 are 1 in 6.3 or 1 to 5.3
more than +2.0 are 1 in 44 or 1 to 43
more than +3.0 are 1 in 741 or 1 to $740^{8}$

The deviation index, therefore, may be converted into "betting odds," expressing the chances that any normal person, selected at random, will be found to have a pressure deviating from the average as much as, or more than, that of the patient under examination. If, for instance, a patient has a systolic pressure of $80 \mathrm{~mm}$. and the deviation index of $80 \mathrm{~mm}$. is -2 , we compare this pressure with the odds of 1 in 44, or 1 to 43 , that any normal individual of the same age and sex will be found to have a pressure of $80 \mathrm{~mm}$. or less. In the language of the race track, this is a "long shot" but one with a chance to win-

7. The - sign signifies deviation below the average, and the + sign, deviation above the average.

8. Table 1 gives more complete figures. 
the patient may be normal. When the odds mount to 1 to 740 , as they do at D.I. \pm 3 , the chances of "winning" - of normality-become small indeed. For practical purposes, they will, we think, be granted to amount to a certainty of "loss"- the individual cannot be regarded as normal-the limits of the normal range have been passed.

THE RANGE

We may, therefore, make certain deductions from the frequency method as to probable normal range. The result, however, is not one

TABLE 1

\begin{tabular}{|c|c|c|c|c|}
\hline D. I. & Per $\stackrel{\text { B }}{\text { Cent. }}$ & Per $\stackrel{\text { Cent. }}{\text { Cent. }}$ & $\underset{\text { Chances }}{\text { D }}$ & $\underset{\text { Chances }}{\mathbf{E}}$ \\
\hline $\begin{array}{l}+0.0 \\
0.1 \\
0.2 \\
0.3 \\
0.4 \\
0.5 \\
0.6 \\
0.7 \\
0.8 \\
0.9 \\
1.0 \\
1.1 \\
1.2 \\
1.3 \\
1.4 \\
1.5 \\
1.6 \\
1.7 \\
1.8 \\
1.9 \\
2.0 \\
2.1 \\
2.2 \\
2.3 \\
2.4 \\
2.5 \\
2.6 \\
2.7 \\
2.8 \\
2.9 \\
3.0 \\
3.1 \\
3.2 \\
3.3 \\
3.4 \\
3.5 \\
4.0 \\
5.0\end{array}$ & $\begin{array}{c}0.0 \\
4.0 \\
7.9 \\
11.8 \\
15.5 \\
19.2 \\
22.6 \\
25.8 \\
28.8 \\
31.6 \\
34.1 \\
36.4 \\
38.5 \\
40.3 \\
41.9 \\
43.3 \\
44.5 \\
45.5 \\
46.4 \\
47.1 \\
47.5 \\
48.2 \\
48.6 \\
48.9 \\
49.2 \\
49.4 \\
49.5 \\
49.6 \\
49.7 \\
49.8 \\
49.86 \\
49.90 \\
49.98 \\
49.95 \\
49.97 \\
49.98 \\
49.997 \\
49.99997\end{array}$ & $\begin{array}{l}50.0 \\
46.0 \\
42.1 \\
38.2 \\
34.5 \\
30.8 \\
27.4 \\
24.2 \\
21.2 \\
18.4 \\
15.9 \\
15.6 \\
11.5 \\
9.7 \\
8.1 \\
6.7 \\
5.5 \\
4.5 \\
3.6 \\
2.9 \\
2.3 \\
1.8 \\
1.4 \\
1.1 \\
0.8 \\
0.6 \\
0.5 \\
0.4 \\
0.3 \\
0.2 \\
0.14 \\
0.10 \\
0.07 \\
0.05 \\
0.03 \\
0.02 \\
0.003 \\
0.00003\end{array}$ & $\begin{array}{r}1 \text { in } 2 \\
2.2 \\
2.4 \\
2.6 \\
2.9 \\
3.2 \\
3.7 \\
4.1 \\
4.5 \\
5.4 \\
6.3 \\
7.3 \\
8.7 \\
10 \\
12 \\
15 \\
18 \\
22 \\
28 \\
35 \\
44 \\
56 \\
72 \\
93 \\
122 \\
162 \\
213 \\
286 \\
278 \\
527 \\
741 \\
1,030 \\
1,450 \\
2,070 \\
2,940 \\
4,270 \\
31,550 \\
3,448,280\end{array}$ & $\begin{array}{r}1 \text { to } 1 \\
1.2 \\
1.4 \\
1.6 \\
1.9 \\
2.2 \\
2.7 \\
3.1 \\
3.5 \\
4.4 \\
5.3 \\
6.3 \\
7.7 \\
9.3 \\
11 \\
14 \\
17 \\
21 \\
27 \\
34 \\
43 \\
55 \\
71 \\
92 \\
121 \\
161 \\
212 \\
285 \\
277 \\
526 \\
740 \\
1,030 \\
1,430 \\
2,070 \\
2,940 \\
4,270 \\
31,550 \\
3,448,280\end{array}$ \\
\hline
\end{tabular}

Column B: percentage of cases normally found between D.I. and mean, or average (D. I. $=0$ ).

Column C: percentage of cases showing a greater deviation from nean in the same direction.

Column D: chances that a normal individual will show the same or a greater deviation from mean in the salne direction.

Column E: chances for to chances against, a normal individual deviating more from mean; i. e., having larger D. I.

absolute range, within which every measurement is normal and without which everything is abnormal, but an arrangement much more like the actual subdivision of cases made roughly by all clinicians. By means of the deviation index, we can, perhaps, state fairly that deviations of less than 1 are unquestionably normal, while deviations of more than 3 are almost certainly abnormal, but between these two limits there is a 


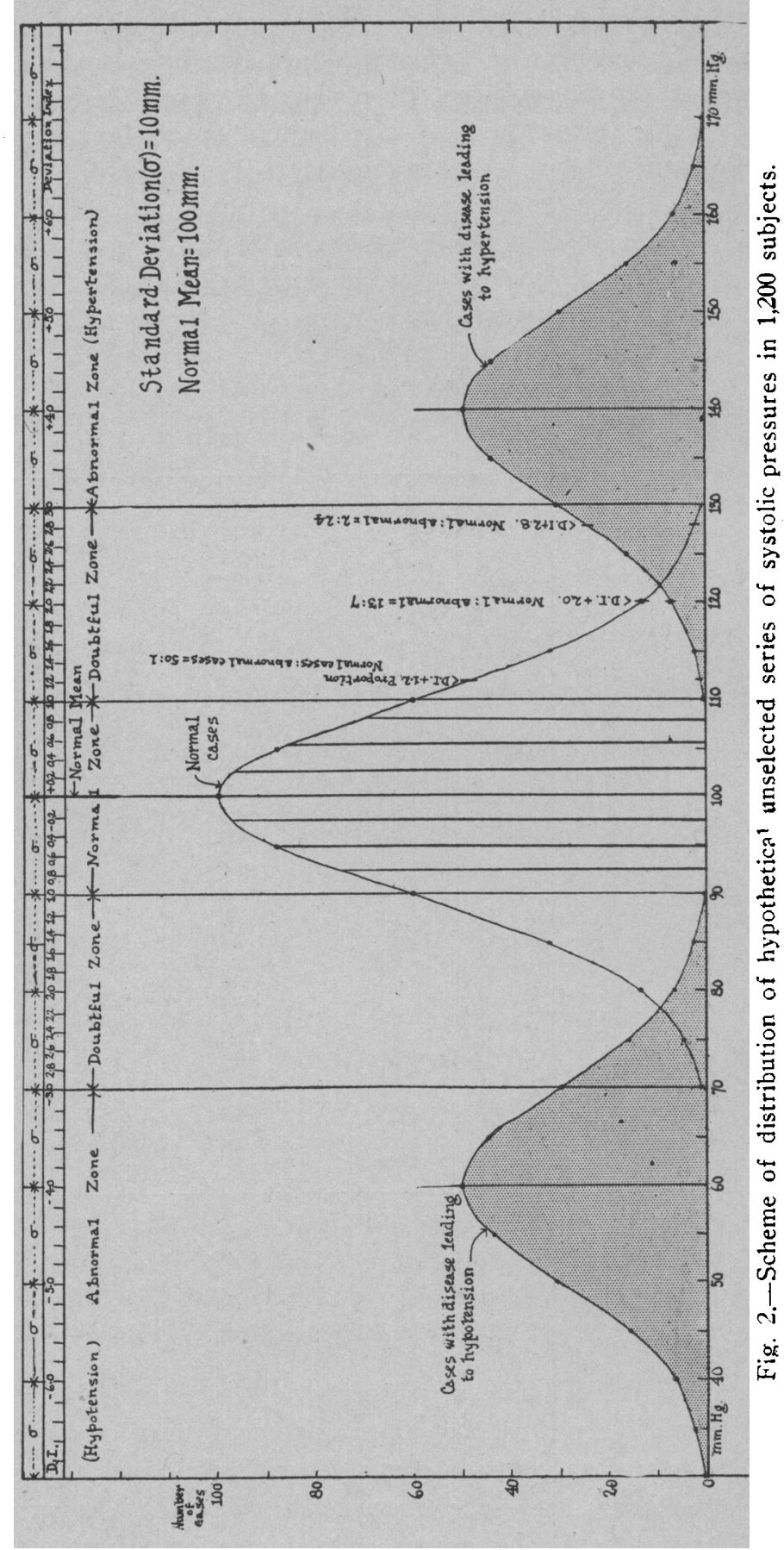

Downloaded From: http://archpedi.jamanetwork.com/ by a Southern Illinois University - Carbondale User on 06/04/2015 
doubtful zone, where measurements may occur in either normal or pathological cases. The reason for this will be made clear by consulting Figure 2, showing schematically the distribution of pressures in a single unselected series of patients with and without disease affecting vascular tension.

Within the doubtful zone it will be seen that both the normal and pathologic cases are represented, but it will be noted also, that as the distance from the normal average increases, the number of normal cases decreases, and the number of abnormal cases increases. It will,

TABle 2.-Distribution of Systolic Pressure

\begin{tabular}{rrrc}
\hline \hline Mm. & Number of Cases & Mm. & $\begin{array}{c}\text { Number } \\
\text { of Cases }\end{array}$ \\
$75-79$ & 1 & $105-109$ & 73 \\
$80-84$ & 4 & $110-115$ & 34 \\
$85-89$ & 14 & $115-119$ & 4 \\
$90-94$ & 20 & $120-124$ & 7 \\
$95-99$ & 91 & $125-129$ & 1 \\
$100-104$ & 160 & & \\
\hline
\end{tabular}

Average, $102.5 \mathrm{~mm}$. Standard deviation, $6.76 \mathrm{~mm}$.

Table 3.-Ideal Distribution of Cases Enumarated in Table 2

\begin{tabular}{ccccc}
\hline \hline Mm. & $\begin{array}{c}\text { Actual } \\
\text { Number }\end{array}$ & $\begin{array}{c}\text { Ideal } \\
\text { Number }\end{array}$ & $\begin{array}{c}\text { Deviation* } \\
\text { Mm. }\end{array}$ & $\begin{array}{c}\text { Deviation } \\
\text { Index (D.I.)* }\end{array}$ \\
$75-79$ & 1 & 0 & -25 & -3.7 \\
$80-84$ & 4 & 2 & -20 & -2.96 \\
$85-89$ & 14 & 10 & -15 & -2.22 \\
$90-94$ & 20 & 41 & -10 & -1.48 \\
$95-99$ & 91 & 93 & -5 & -0.74 \\
$100-104$ & 160 & 118 & +0 & 0 \\
$105-109$ & 73 & 93 & +5 & +0.74 \\
$110-114$ & 34 & 41 & +10 & +1.48 \\
$115-119$ & 4 & 10 & +15 & +2.22 \\
$120-124$ & 7 & 2 & +20 & +2.96 \\
$125-129$ & 1 & 0 & +25 & +3.7 \\
& & & &
\end{tabular}

* Of the midpoint of each interval.

therefore, be seen that the deviation index, measuring the probabilities as they increase or decrease with the distance from the central average, is the true measure by which to estimate the significance of any observation, and the only measure by which observations in the doubtful zone can be evaluated.

ORGANization OF ACTUAL STATISTICS

Actual series of clinical observations, unless they be very large, or of a nature which makes it extraordinarily simple to exclude abnormal data, rarely follow exactly the ideal frequency distribution. It is, however, possible to compute with fair approach to the absolute values 
both the standard deviation and the mean, or average, from a relatively small number of observations. The degree of inaccuracy can also be computed. Once the standard deviation and mean have been found, the ideal distribution can be calculated and the range limits, above discussed, determined. It will, perhaps, assist the reader to give an example which will illustrate the principles involved, the method by which our final tables were calculated and the method by which they can be applied practically.

In the group of boys between 9 and 11 years, the 409 observations of systolic pressure were distributed as shown in Table 2 .

Applying the standard deviation as the controlling factor in frequency distributions, we can determine approximately the ideal distribution of these cases as shown in Table 3 .

The curves for the actual and theoretical distribution are shown in Figure 3 .

Taking the standard deviation (D.I. $=1$ ) as the range of absolute normal, and three times the standard deviation (D.I. $=3$ ) as the inner limit of the absolutely abnormal, the three ranges would be:

Normal : $102.5 \mathrm{~mm} . \pm 6.76 \mathrm{~mm} .=95.74 \mathrm{~mm}$. to $109.26 \mathrm{~mm}$., or 96 $-109 \mathrm{~mm}$.

Doubtful : $102.5 \mathrm{~mm} . \pm 6.76$ to $102.5 \mathrm{~mm} . \pm 3 \times 6.76=82.3-$ 95.7 and $109.3-122.8 \mathrm{~mm}$., or $82-96 \mathrm{~mm}$. and $109-123 \mathrm{~mm}$.

Abnormal : $102.5 \mathrm{~mm} . \pm<3 \times 6.76 \mathrm{~mm}$. $=$ under 82.3 , over 122.8 $\mathrm{mm}$, or under $82 \mathrm{~mm}$. and over $123 \mathrm{~mm}$.

\section{METHODS OF APPLICATION}

Let us now suppose that we have examined a boy aged 10, and have found his systolic pressure to be $125 \mathrm{~mm}$. The average being $102.5 \mathrm{~mm}$. for boys of this age, his deviation is ${ }^{9}$

$$
125-102.5=+22.5 \mathrm{~mm} \text {. }
$$

Since the standard deviation has been found to be $6.76 \mathrm{~mm}$., the deviation index is

$$
\frac{+22.5}{6.76}=+3.33
$$

Reference to Table 1 will show (a) that out of 1,000 normal cases more than 999 will have a smaller index; (b) that less than 0.1 per cent. of normal cases have an index as large; (c) that the chances that a given individual, if normal, will have an index as large are less than 1 to 2,070 . By the definitions of the three zones, we note that an index of 3 or over places the individual in the abnormal zone. Hence, we can state that this individual is suffering from pathologic hypertension.

9. The sign indicating whether the pressure is above or below the average is kept throughout. 


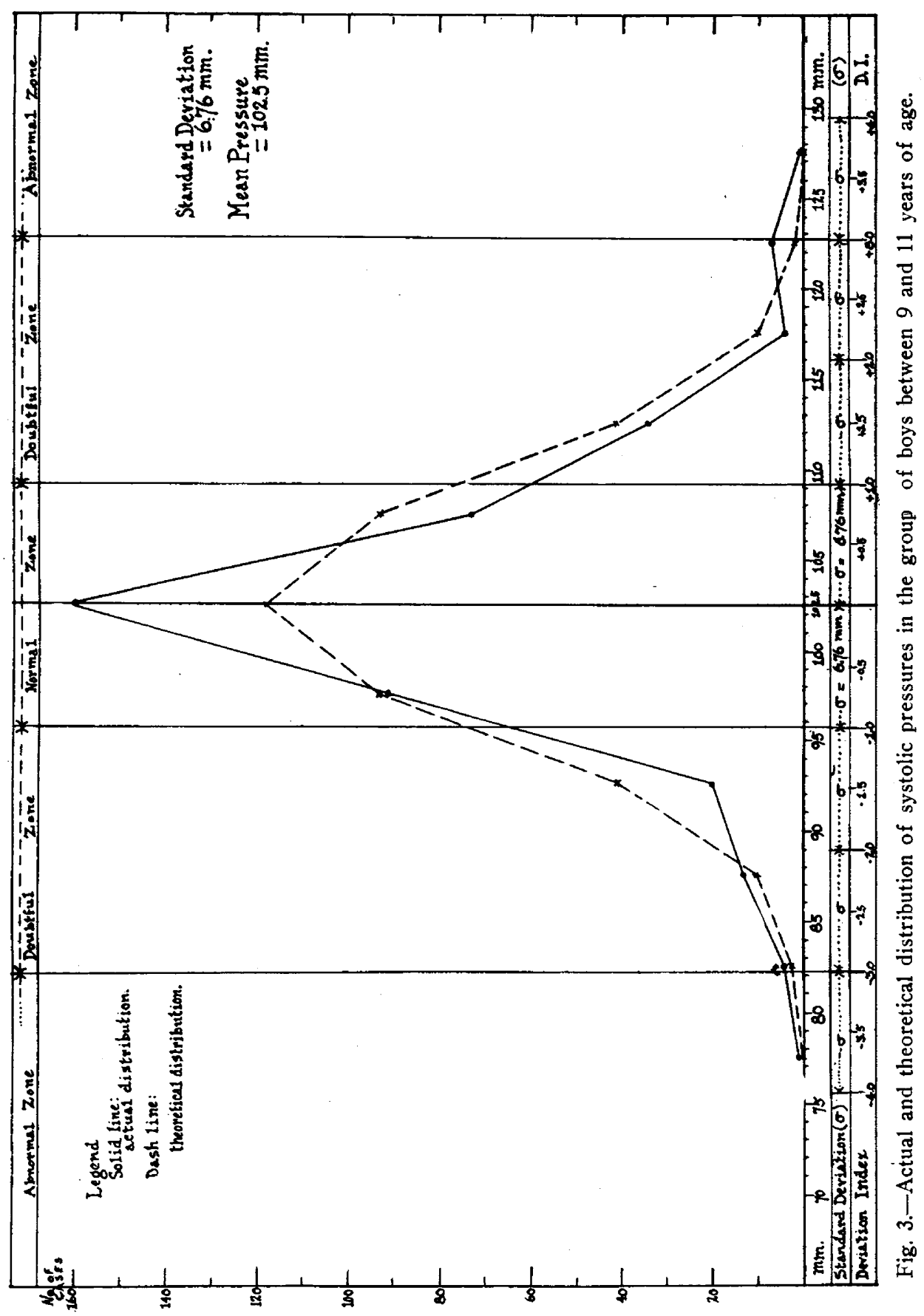


Again, apply the method to a boy aged 10 with a systolic pressure of $116 \mathrm{~mm}$. The deviation of $+13.5 \mathrm{~mm}$. gives an index of +2 , placing the reading between 1 and 3 , or in the doubtful zone. Since only 2.3 per cent. of normal cases have an index less than this, we may regard the case as decidedly suspicious, but not definitely pathological, unless so determined by other tests or symptoms. Such a case would, however, be one for further careful investigation.

Another patient of the same age and sex with a pressure of $96 \mathrm{~mm}$., having a deviation of $-6.5 \mathrm{~mm}$. and a D.I. of -0.97 would be within the normal limit of 1 and without further consideration be regarded as normal.

While the accurate evaluation of "chances" requires a table of values (Table 1), one learns, after applying the method a few times, the relative significance of the various values for D.I., and for practical purposes can often dispense with the table. One thinks of a given pressure as $\mathbf{a}+2.5$ pressure, or $\mathbf{a}-3$ pressure, or $\mathrm{a}+0.4$ pressure, these terms having come to assume much more significance than the mere level of the mercury column alone.

It need hardly be said that the method is applicable to diastolic and pulse pressure as well as to systolic pressure. It is also applicable to pulse rates, and to the pulse rate-pulse pressure product which has been considerably used as an index of cardiac output. For all these we have constructed tables for clinical use.

\section{DESCRIPTION OF MATERIAL}

The observations on which the present study is based were made personally by us (to keep the personal factor as constant as possible) on 651 boys and 450 girls (1,101 individuals), and comprise a total of 2,710 measurements of systolic and diastolic pressures. Large as is the number, the necessity of grouping the data into age classes, as shown in Table 4, with different means and deviations, has reduced the reliability of our conclusions. The reliability of means increases as the square root of the number of variates; that of the standard deviations as the square root of twice the number of variates. It was, therefore, recognized that in order materially to increase the approximation of our results to the absolute, would require an enormous increase in the number of observations, a task beyond our powers, or the material at hand. Some idea of the accuracy of our means can be obtained by comparison with the figures of other writers, notably those of Judson and Nicholson. ${ }^{10}$ Unfortunately for us, the readings of most other workers have either been taken under different conditions or by other

10. Judson, C. F. and Nicholson, P.: Blood Pressure in Normal Children, Am. J. Dis. Child. 8:257 (Sept.) 1914. 
methods. Judson and Nicholson, using a modified Erlanger instrument (checking the auscultatory method), and examining children lying down, found an average systolic pressure of 91.6 at age 4, for both sexes, and of 106.1 at age 14 . Katzenberger, ${ }^{11}$ using the auscultatory method obtained values of 93 at age 4 and 119 at age 14 . Our values for the two sexes are 88.9 at age 4 and 109.6 at age 14 . In diastolic pressure our readings do not correrspond closely with those of Judson and Nicholson, who failed to find any constant variation with age, though their figures show considerable irrregular fluctuation. It is possible that the difference in position may account for the discrepancy between our figures and theirs. Katzenberger found, as we did, a progressive rise in diastolic pressure, but the figures themselves are not comparable because he used the fifth phase as the diastolic point. Dif-

TABLE 4.-Distribution OF Data

\begin{tabular}{|c|c|c|c|c|}
\hline \multirow{2}{*}{ Age } & \multicolumn{2}{|c|}{ Number of Individuals } & \multicolumn{2}{|c|}{ Number of Observations } \\
\hline & Boys & Girls & Boys & Girls \\
\hline 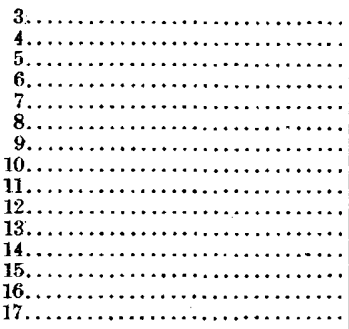 & $\begin{array}{l}12 \\
23 \\
27 \\
51 \\
50 \\
46 \\
68 \\
47 \\
60 \\
54 \\
79 \\
42 \\
49 \\
30 \\
13\end{array}$ & $\begin{array}{r}7 \\
19 \\
14 \\
24 \\
32 \\
45 \\
57 \\
43 \\
17 \\
53 \\
37 \\
32 \\
17 \\
18\end{array}$ & $\begin{array}{r}22 \\
29 \\
57 \\
108 \\
102 \\
113 \\
144 \\
121 \\
144 \\
136 \\
174 \\
125 \\
172 \\
87 \\
36\end{array}$ & $\begin{array}{r}16 \\
50 \\
29 \\
54 \\
72 \\
128 \\
155 \\
109 \\
118 \\
140 \\
87 \\
82 \\
45 \\
49 \\
6\end{array}$ \\
\hline 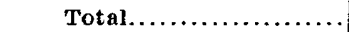 & 651 & 450 & $1, \overline{570}$ & 1,140 \\
\hline Total both sexes.......... & \multicolumn{2}{|c|}{1,101} & \multicolumn{2}{|c|}{2,710} \\
\hline
\end{tabular}

ferences in method, therefore, make it impossible to combine the various collections of data in order to increase the accuracy of the results.

In examining our children, cards were made out showing age to the nearest birthday, sex, weight, height, sitting height, pulse, systolic and diastolic pressures; date, time of day; remarks on diagnosis or anything unusual in the history or physical examination. The majority of readings were taken between $9: 30 \mathrm{a} . \mathrm{m}$. and noon. A certain number of cases were excluded from our normal series on suspicion of abnormality in physical condition. An effort was made to take three consecutive readings of blood pressure and, simultaneously, of pulse, but this was not done in every case.

The auscultatory method was used with a cuff suited in width to the arm. About 90 per cent. of the measurements were taken with a

11. Katzenberger, A.: Puls und Blutiruck bei gesunden Kindern, Ztschr, f. Kinderh. 9:167, 1913. 
$10 \mathrm{~cm}$. cuff, and the remainder either with a $7.5 \mathrm{~cm}$. cuff for the smallest children, or with the adult $12.5 \mathrm{~cm}$. cuff for the largest. The stethoscope was applied below the cuff, as lightly as possible. All readings

TABle 5.-Systolic Pressures

\begin{tabular}{|c|c|c|c|c|c|c|}
\hline Age & & $\stackrel{1}{\text { Mean }}$ & 4 P. E. & ${ }^{3}$ & $4 \mathrm{P}^{4} \mathrm{E}$. & $\stackrel{5}{\mathbf{5}}$ \\
\hline $3-4-5$ & Boys.................. & 89.4 & 1.4 & 5.32 & 0.96 & 107 \\
\hline \multirow[t]{2}{*}{$4-5-6$} & 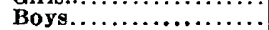 & $\begin{array}{l}\infty .8 .3 \\
92.8\end{array}$ & $\begin{array}{l}1.0 \\
1.2\end{array}$ & $\begin{array}{l}0.04 \\
6.20\end{array}$ & 0.84 & $\begin{array}{r}30 \\
192\end{array}$ \\
\hline & Girls.. & 90.7 & 1.5 & 6.24 & 1.04 & 133 \\
\hline \multirow[t]{2}{*}{$5-6-7$} & Boys.: & 94.5 & 1.1 & 6.38 & 0.76 & 263 \\
\hline & Girls..... & 93.8 & 1.6 & 7.30 & 1.12 & 152 \\
\hline \multirow[t]{2}{*}{$6-7-8$} & Boys.................... & 97.3 & 1.0 & 6.65 & 0.68 & 321 \\
\hline & Girls.... & 97.3 & 1.2 & 7.36 & 0.88 & 249 \\
\hline \multirow[t]{2}{*}{$7-8-9$} & Boys... & 99.2 & 0.9 & 6.54 & 0.68 & 354 \\
\hline & Girls... & 100.2 & 1.0 & 7.06 & 0.68 & 352 \\
\hline \multirow[t]{2}{*}{$8-9-10$} & Boys... & 100.9 & 0.8 & 6.02 & 0.56 & 373 \\
\hline & Girls................... & 101.2 & 0.9 & 6.79 & 0.68 & 387 \\
\hline \multirow[t]{2}{*}{$2-10-11$} & Boys....................... & 102.4 & 0.9 & 6.64 & 0.64 & 407 \\
\hline & Girls... & 102.6 & 1.0 & 7.06 & 0.68 & 380 \\
\hline \multirow[t]{2}{*}{$10-11-12$} & Boys. & 104.1 & 0.9 & 6.61 & 0.64 & 402 \\
\hline & Girls..................... & 104.3 & 1.1 & 7.64 & 0.76 & 365 \\
\hline \multirow[t]{2}{*}{ 11-12-13 } & Boys................... & 105.9 & 0.8 & 6.73 & 0.60 & 456 \\
\hline & Girls..................... & 106.2 & 1.0 & 7.08 & 0.68 & 342 \\
\hline \multirow[t]{2}{*}{$12-13-14$} & Boys.......................... & 107.6 & 0.8 & 6.02 & 0.56 & 426 \\
\hline & Girls $\ldots \ldots \ldots \ldots \ldots \ldots \ldots \ldots \ldots \ldots \ldots$ & 108.1 & 1.0 & 6.17 & 0.68 & 305 \\
\hline \multirow[t]{2}{*}{$13-14-15$} & Boys........................ & 110.1 & 0.8 & 6.72 & 0.60 & 467 \\
\hline & Girls.......................... & 109.5 & 1.2 & 6.31 & 0.84 & 209 \\
\hline \multirow{2}{*}{ J4-15-16 } & 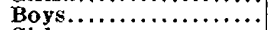 & 112.2 & 1.0 & 7.05 & 0.76 & 375 \\
\hline & Girls............ & 112.7 & 1.4 & 6.79 & 1.00 & 17 \\
\hline \multirow{2}{*}{$15-16-17$} & Boys........................ & 115.3 & 1.1 & 7.00 & 0.76 & 292 \\
\hline & 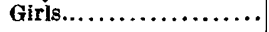 & 114.3 & 2.1 & 7.82 & 1.48 & 102 \\
\hline
\end{tabular}

"4 P. E." (4 times the probable error), Column 2, indicates the limits of reliability for the mean; and 4 P. F. Column 4 , for the standard deviation. The true mean or the true and 3 . Column 5 gives the number of observations includer in the final calculations after elimination of extreme variates.

TABLE 6.-Diastolic Pressures

\begin{tabular}{|c|c|c|c|c|c|c|}
\hline Age & & Mean & 4 P. E. & $\sigma$ & 4 P. E. & Number \\
\hline $3-4-5$ & Boys................ & 60.3 & 1.8 & 6.75 & 1.24 & 108 \\
\hline & 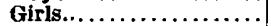 & 59.8 & 1.9 & 6.70 & 1.32 & 93 \\
\hline \multirow{2}{*}{$4-5-6$} & Boys............... & 62.7 & 1.5 & 7.85 & 1.08 & 194 \\
\hline & Girls............... & 62.3 & 1.4 & 6.05 & 1.00 & 129 \\
\hline \multirow[t]{2}{*}{$5-6-7$} & Boys................... & 64.0 & 1.3 & 7.70 & 0.92 & 263 \\
\hline & Girls............. & 64.1 & 1.7 & $\mathbf{7 . 5 0}$ & 1.16 & 153 \\
\hline \multirow{2}{*}{$6-7-8$} & Boys........... & 65.4 & 1.1 & 7.27 & 0.76 & 319 \\
\hline & Girls.............. & 66.0 & 1.3 & 7.57 & 0.84 & 251 \\
\hline \multirow[t]{2}{*}{$7-8-9$} & 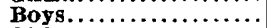 & 66.7 & 1.0 & 7.00 & 0.72 & 356 \\
\hline & Girls............. & 67.9 & 1.0 & 7.29 & 0.76 & 353 \\
\hline \multirow[t]{2}{*}{$8-9-10$} & Boys. . . & 67.8 & 1.0 & 6.89 & 0.68 & 379 \\
\hline & 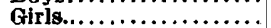 & 69.4 & 0.9 & 6.45 & 0.64 & 389 \\
\hline \multirow[t]{2}{*}{$9-10-11$} & 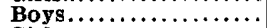 & 68.9 & 0.8 & 5.88 & 0.56 & 409 \\
\hline & Girls............... & 70.3 & 0.9 & 6.62 & 0.64 & 379 \\
\hline \multirow[t]{2}{*}{$10-11-12$} & 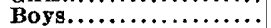 & 69.9 & 0.7 & 5.12 & 0.48 & 397 \\
\hline & Girls.................. & 71.4 & 0.9 & 6.53 & 0.68 & 364 \\
\hline \multirow[t]{2}{*}{$11-12-13$} & 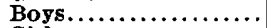 & 71.1 & 0.6 & 4.82 & 0.44 & 449 \\
\hline & Girls.............. & 71.9 & 1.0 & 6.80 & 0.72 & 34 ? \\
\hline \multirow[t]{2}{*}{$12-13-14$} & 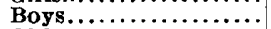 & 71.9 & 0.6 & 4.90 & 0.44 & 431 \\
\hline & 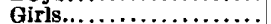 & 73.0 & 1.0 & 7.15 & 0.72 & 306 \\
\hline \multirow[t]{2}{*}{$13-14-15$} & 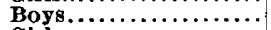 & 73.3 & 0.6 & 4.78 & 0.44 & 465 \\
\hline & Girls............ & 73.5 & 1.6 & 8.50 & 1.12 & 213 \\
\hline \multirow[t]{2}{*}{$14-15-16$} & 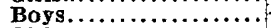 & 74.6 & 0.8 & 5.94 & 0.56 & 383 \\
\hline & Girls............... & 76.4 & 2.0 & 10.00 & 1.44 & 175 \\
\hline \multirow[t]{2}{*}{$15-16-17$} & 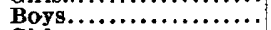 & 75.8 & 1.0 & 6.18 & 0.68 & 294 \\
\hline & Girls.................. & 79.1 & 2.6 & 9.90 & 1.84 & $10 \overline{3}$ \\
\hline
\end{tabular}

were made with the mercury falling. All patients were in the sitting position with the arm horizontal, resting on a table. A brief preliminary rest was given. If the first measurement showed a striking dis- 
crepancy from the next two, a fourth was taken and the first discarded. This was done because the excitement of the first application of the cuff, sometimes raised the pressure considerably. As a rule, this rapidly

TABle 7.-Pulse Pressurfs

\begin{tabular}{|c|c|c|c|c|c|c|}
\hline Age & & Mean & 4 P. E. & $\boldsymbol{\sigma}$ & 4 P. E. & Number \\
\hline $3-4-5$ & 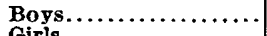 & 29.6 & 1.8 & 6.75 & 1.24 & 108 \\
\hline $4-5-6$ & 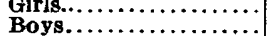 & $\begin{array}{l}29.6 \\
30.6\end{array}$ & $\begin{array}{l}1.7 \\
1.3\end{array}$ & $\begin{array}{l}6.08 \\
6.45\end{array}$ & $\begin{array}{l}1.20 \\
0.88\end{array}$ & $\begin{array}{r}94 \\
193\end{array}$ \\
\hline & Girls................... & 29.6 & 1.5 & 6.25 & 1.04 & 131 \\
\hline $5-6-7$ & 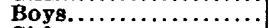 & 31.1 & 1.0 & 5.69 & 0.68 & 264 \\
\hline & Girls................. & 29.8 & 1.5 & 6.65 & 1.04 & 151 \\
\hline $6-7-8$ & Boys................ & 32.0 & 0.9 & 6.00 & 0.64 & 322 \\
\hline & Girls. $\ldots, \ldots \ldots \ldots, \ldots \ldots$ & 31.7 & 0.9 & 5.14 & 0.60 & 250 \\
\hline $7-8-9$ & Boys................. & $33.1^{\circ}$ & 0.8 & 5.73 & 0.60 & 353 \\
\hline $8-9-10$ & Giris $\ldots \ldots \ldots \ldots \ldots \ldots \ldots$ & 32.4 & 0.8 & 5.17 & 0.52 & 346 \\
\hline & 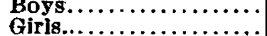 & $\begin{array}{l}33.8 \\
32.1\end{array}$ & 0.8 & $\begin{array}{l}5.59 \\
5.21\end{array}$ & $\begin{array}{l}0.56 \\
0.52\end{array}$ & 371 \\
\hline $9-10-11$ & 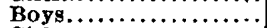 & 33.9 & 0.8 & 5.72 & 0.56 & 406 \\
\hline & Girls.................... & 32.3 & 1.0 & 6.78 & 0.68 & 375 \\
\hline 10-11-12 & 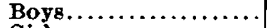 & 34.6 & 0.8 & 6.20 & 0.60 & 397 \\
\hline & Girls.................. & 32.9 & 0.9 & 6.57 & 0.68 & 359 \\
\hline $11-12-13$ & Boys.................. & 35.2 & 0.8 & 6.34 & 0.56 & 450 \\
\hline $12-13-14$ & Girls................... & 33.6 & $\begin{array}{l}1.0 \\
0.8\end{array}$ & 6.89 & 0.72 & 338 \\
\hline $12-13-14$ & 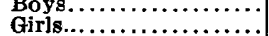 & $\begin{array}{l}36.1 \\
35.2\end{array}$ & $\begin{array}{l}0.8 \\
1.0\end{array}$ & $\begin{array}{l}6.23 \\
6.46\end{array}$ & $\begin{array}{l}0.56 \\
0.72\end{array}$ & $\begin{array}{l}434 \\
302\end{array}$ \\
\hline $13-14-15$ & 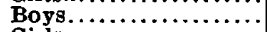 & 37.5 & 0.7 & 5.97 & 0.53 & 470 \\
\hline $74 \quad 159$ & 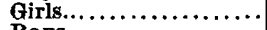 & 35.3 & 1.5 & 7.32 & 0.96 & 207 \\
\hline $14-15-16$ & Boys...................... & 38.5 & 0.8 & 6.07 & 0.60 & 384 \\
\hline $15-16-17$ & 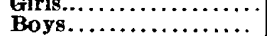 & $\begin{array}{l}36.1 \\
39.6\end{array}$ & $\begin{array}{l}1.7 \\
1.0\end{array}$ & $\begin{array}{l}8.38 \\
6.43\end{array}$ & $\begin{array}{l}1.20 \\
0.71\end{array}$ & $\begin{array}{l}174 \\
294\end{array}$ \\
\hline & Girls............ & 34.7 & 1.8 & 6.91 & 1.28 & 106 \\
\hline
\end{tabular}

TABLE 8.-Pulse Rates

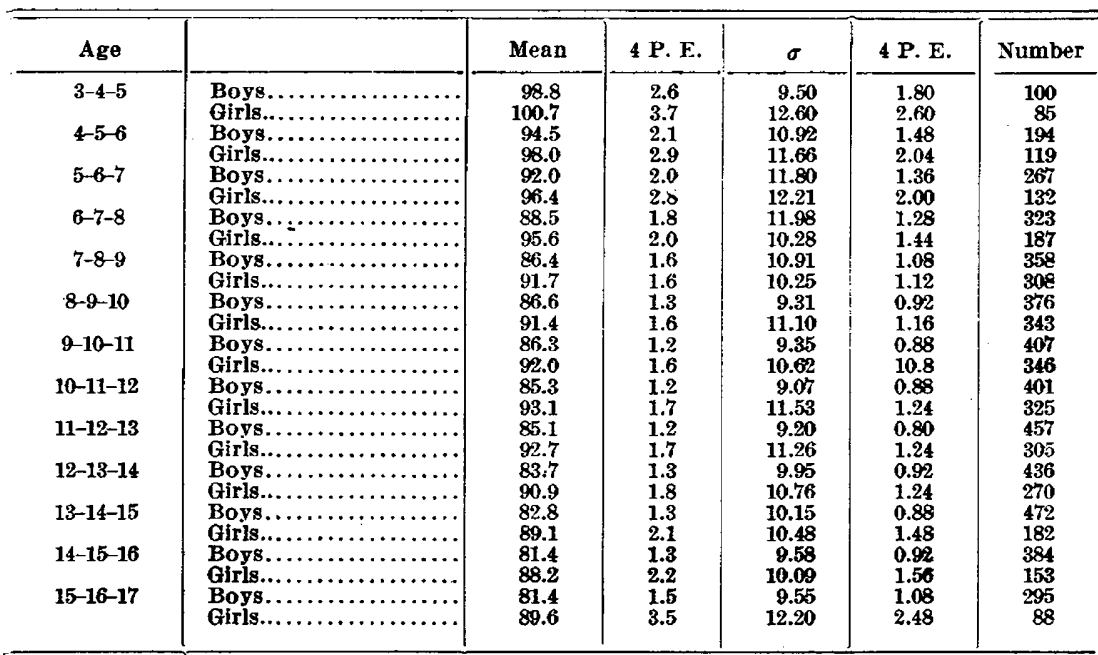

The necessity of counting pulse over 15 second periods and multiplying by four has introduced a technical difficulty in class interval distribution, while multiplying the observational error, which is probably considerable when pulse is taken by palpation in children. Our pulse rate values are, therefore, approximate only, both for the mean and for the standard deviation.

subsided and the children were not further disturbed by the test. Systolic pressure was taken as the point at which the first clear, continuous sounds appeared; the diastolic, at the fourth phase. The pulse 
was taken by an assistant. The phases are nearly always distinctly marked after the third year, but they are often better elicited after the arm is raised and the hand clenched and unclenched a few times. Most of the children were school children, but about 150 were patients in the Children's Clinic suffering from minor complaints who appeared to be for practical purposes normal.

In compiling our statistics, frequency distributions were tabulated for age groups of three years ${ }^{12}$ using class intervals of $5 \mathrm{~mm}$. of mercury and the mean and standard deviation computed from each distribution was assigned to the middle year. Thus, the group 3-4-5 was taken as the type of year 4; 4-5-6, of year 5 , and so on. This method was adopted when it was found that the number of measures in each

TABle 9.-Pulse Pressure-Pulse Product

\begin{tabular}{|c|c|c|c|c|c|c|}
\hline Age & . & Mean & 4 P. E. & $\sigma$ & A P. F. & Number \\
\hline $3-4-5$ & Boys........... & 2880 & 180 & 653 & 128 & 100 \\
\hline & Girls...................... & 2880 & 2.10 & 700 & 148 & 84 \\
\hline $4-5-6$ & Boys........................ & 2830 & 130 & 671 & 92 & 194 \\
\hline & Boys.. & 2850 & 170 & 679 & 120 & 118 \\
\hline $5-6-7$ & Boys............... & 2800 & 100 & 624 & 72 & 267 \\
\hline & Girls............. & 2680 & 140 & 585 & 100 & 127 \\
\hline $6-7-8$ & Boys.............. & 2820 & 100 & 645 & 68 & 323 \\
\hline & Girls.............. & 2890 & 120 & 634 & 84 & 205 \\
\hline $7-8-9$ & Boys... & 2850 & 90 & 618 & 64 & 360 \\
\hline & Girls.... & 2900 & 100 & 625 & 68 & 308 \\
\hline $8-9-10$ & Boys................... & 2870 & 90 & 648 & 56 & 377 \\
\hline & Girls.......... & 2890 & 90 & 642 & 68 & 343 \\
\hline $9-10-11$ & Boys....................... & 2870 & 80 & 578 & 56 & $\mathbf{4 0 9}$ \\
\hline & Girls.................... & 2920 & 110 & 731 & 76 & 346 \\
\hline $10-11-12$ & 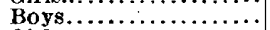 & 2880 & 80 & 550 & 52 & 401 \\
\hline & 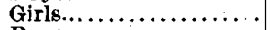 & 3000 & 120 & 786 & 84 & 325 \\
\hline $11-12-13$ & 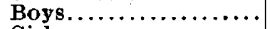 & 2970 & 80 & 643 & .56 & 454 \\
\hline & 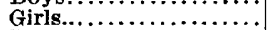 & 3160 & 130 & 821 & 88 & 305 \\
\hline $12-13-14$ & Boys.................. & 3010 & 90 & 707 & 64 & 436 \\
\hline & Girls................... & 3200 & 130 & 781 & 92 & 270 \\
\hline $13-14-15$ & Boys...................... & 3070 & 80 & 669 & 60 & 472 \\
\hline & Girls...................... & 3150 & 160 & 800 & 116 & 182 \\
\hline $14-15-16$ & Boys......................... & 3100 & 90 & 643 & 64 & 385 \\
\hline 121010 & 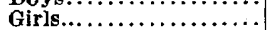 & 3120 & 170 & 781 & 120 & 153 \\
\hline $15-16-17$ & Boys................ & $\begin{array}{l}3070 \\
3010\end{array}$ & $\begin{array}{r}90 \\
190\end{array}$ & $\begin{array}{l}593 \\
664\end{array}$ & $\begin{array}{r}68 \\
136\end{array}$ & $\begin{array}{r}295 \\
88\end{array}$ \\
\hline
\end{tabular}

group was too small to give us a smooth curve. Use was then made of the statistical method of smoothing in which the average of three successive, related measures, $a, b, c$, is taken as the true $b$; thus,

$$
b=\frac{a+b+c}{3} \text { (Rugg, }{ }^{4} \text { p. 184). }
$$

Since we have wished to make the practical use of the tables as simple as possible we have also made a further set of figures which we

12. We disagree with Wolfensen-Kriss ${ }^{13}$ who states that blood pressure varies with height and weight rather than with age. We have plotted our systolic pressures against both height and weight and sitting height and have found that the spread of distribution is just as great for any of these as it is for age. Age appears to be, as a whole, as accurate (and perhaps as fallacious) a measure of development as weight or one of the linear measurements.

13. Wolfensen-Kriss, P.: Ueber den Blitdruck im Kindesalter, Arch. f. Kinderh. 53:332, 1910. 
min.
$\mathrm{Hg}$.

10 SYSTOLIC VARIABILITY 6

$0+-\infty$

o

DiastoLic DarinBility o

10

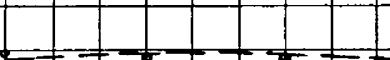

.

120

110

100

\begin{tabular}{lllll}
\hline & & & \\
\hline & & & \\
\hline & & & \\
\hline SYST OLIC \\
PREESSYRE
\end{tabular}

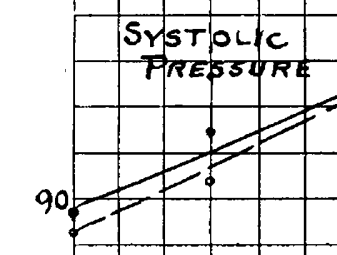

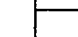

80

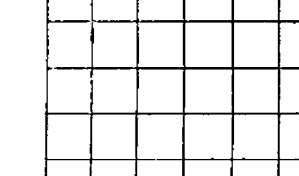

Y.०

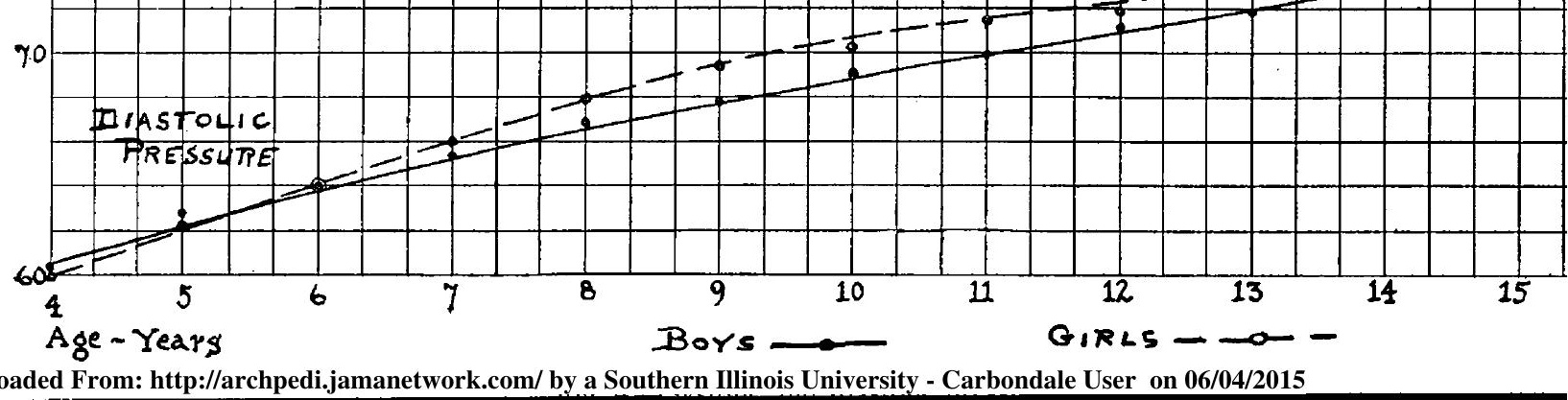


EYSTOLLC Variabifitit 6

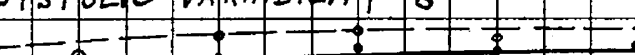
$=0$

JifstoLic DarMB LLITY O

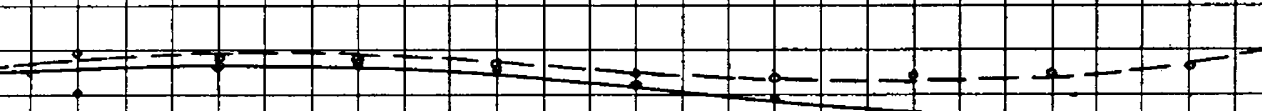

$\rightarrow-7$

instolic

PrRessure

arastowic

PRRESSUTE

\begin{tabular}{llllll|l|l|l|l|l|l|l|l|l|}
\hline \\
\hline
\end{tabular}

\section{-}

$$
+1
$$

$-\frac{1}{2}$

$+$ 

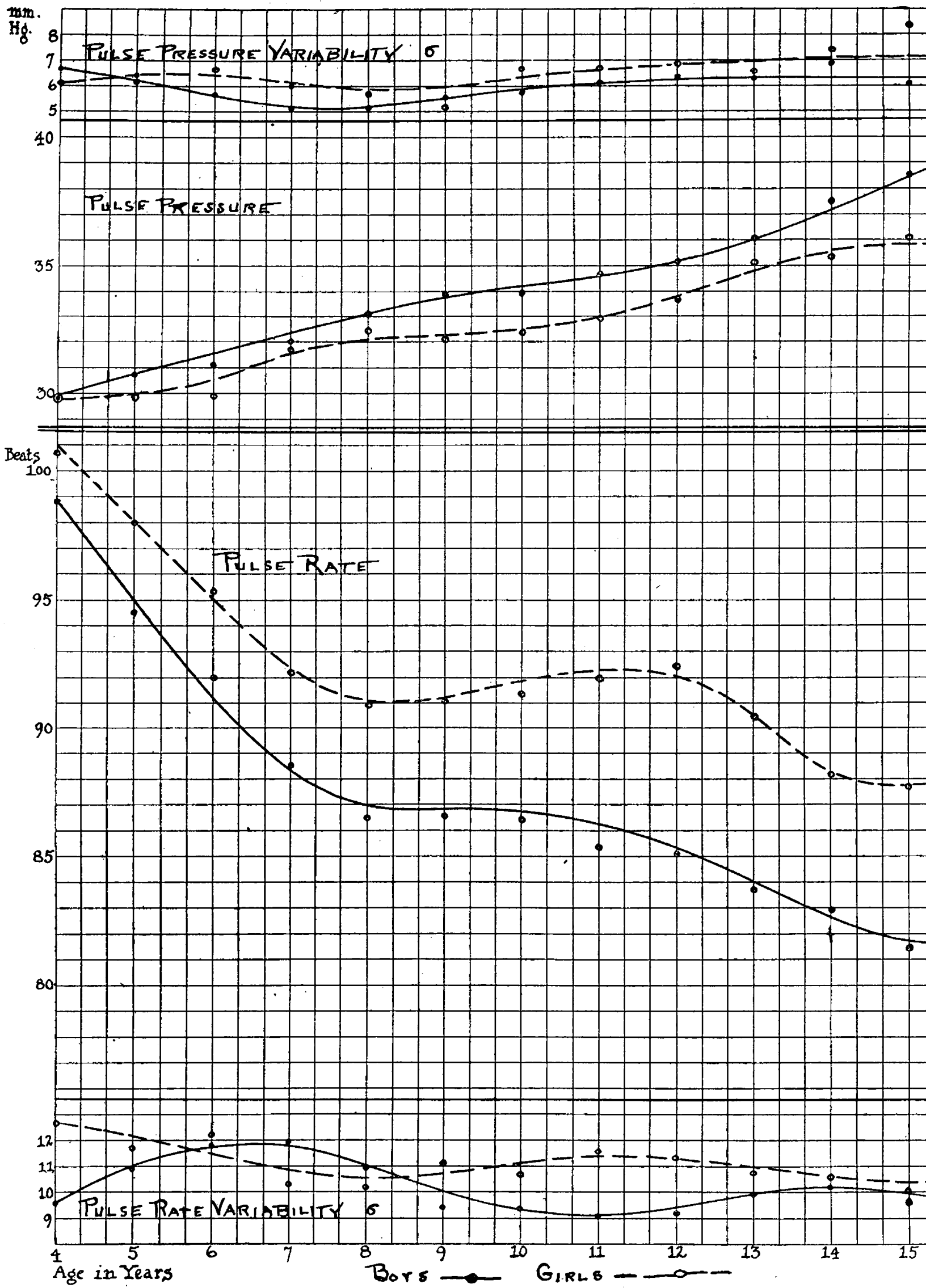

Downloaded From: http://archpedi.jamanetwork.com/ by a Southern Illinois University - Carbondale User on 06/04/2015.ho-two 


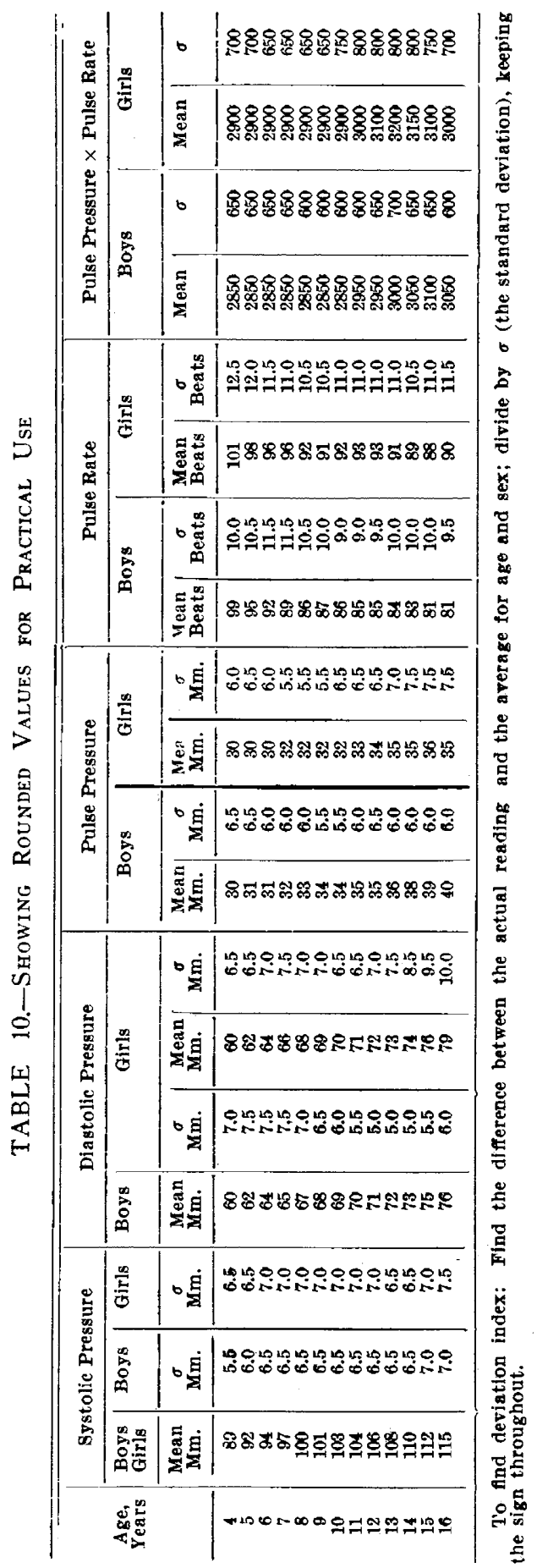

Downloaded From: http://archpedi.jamanetwork.com/ by a Southern Illinois University - Carbondale User on 06/04/2015 
have adopted, and advise, in clinical application. Here we have used "rounded" values, giving our means in the nearest whole number to the "found" mean, and our standard deviations in the nearest half number. $(0.5)$, to the found value after another "smoothing." These assumed or rounded values are in every case within the limits of unreliability, within which the true value should fall. While they may be subject to later correction, they are, we believe, sufficiently accurate to justify their use in practice and to give significant results. The complete tabulations are shown in Tables $5,6,7,8$ and 9.

In each of these tables, the first column shows the mean (average) of the distribution; the second column, the limits of deviation from the "found" mean, within which the true mean probably occurs; the third column shows the standard deviation; and the fourth column, the limits of deviation from the "found" standard deviation within which the true standard deviation probably occurs.

Table 10 gives the rounded values for mean and standard deviation which we have tentatively adopted for actual use.

Figures 4 and 5 show graphically the changes that occur with age in average and variability of systolic pressure, diastolic pressure, pulse pressure and pulse.

\section{COMMENT ON STANDARD CURVES}

The application of the formulas for unreliability permits us to draw certain conclusions regarding the true or absolute values for our standards, which we offer tentatively.

\section{EFFECT OF SEX}

Systolic Pressure.--The mean systolic pressure for the two sexes varies only within the limits of unreliability, and, in the plotted curve the sexes run nearly the same course. It is evident that there is no significant difference in mean systolic pressure. The variation in standard deviation between the sexes is also within the limits of unreliability. Standard deviations, however, show very little age variation and we have tentatively assumed a sex difference because the mean (representing the most probable value of a series) standard deviation is about $6.5 \mathrm{~mm}$. for boys and $7 \mathrm{~mm}$. for girls. We feel safer in doing this because in all our other measurements-diastolic pressure, pulse pressure, pulse and pulse pressure-pulse product - the girls regularly show the same greater mean variability. That this phenomenon is the counterpart of a physiologically greater circulatory lability characteristic of the female sex seems to us highly plausible.

Diastolic Pressure.-A strict interpretation of the found values for diastolic pressure also shows the sexual differences to be within the limits of unreliability. We cannot, therefore, avoid the possibility that 
there may be no actual sex difference. The form of the plotted curve, however, speaks strongly for the existence of an actual difference. After the fifth year the girls constantly show a higher mean pressure, which in some instances closely approaches the limits of unreliability. We have accordingly (subject to correction) assumed small differences after the sixth year in setting our standards. In the case of standard deviations, the situation is different. Here, after the eleventh year, the found differences are greater than the factor for unreliability, and we can definitely assert the presence of true differences. The variability of diastolic pressure in girls after the thirteenth year is very great and in marked contrast to the very small variability of the boys. That this variability in the girls is in some way connected with the vasomotor disturbances of adolescence seems to us to be beyond question.

Pulse Pressure.-Similar considerations may be applied to pulse pressure. Here the sex differences are within the limits of unreliability, but in the later ages so closely approach these limits and the differences throughout after the sixth year are so constantly in one direction, that it has been thought best to assume, tentatively, corresponding differences in the true values for both mean and standard deviation.

TABle 11.-Showing Annual Rate of Increment of Blood Pressures, and of Decrement of Pulse Rate

\begin{tabular}{c|c|c|c|c|c|c|c|c|c}
\hline \multirow{2}{*}{ Age Group } & \multicolumn{2}{|c|}{ Systolle } & \multicolumn{2}{c|}{ Diastolfe } & \multicolumn{2}{c|}{ Pulse Pressure } & \multicolumn{2}{c}{ Pulse Rate } \\
\cline { 2 - 8 } & Boys & Girls & Boys & Girls & Boys & Girls & Boys & Girls \\
\hline 4-9 & 2.3 & 2.5 & 1.5 & 1.9 & 0.8 & 0.5 & 2.5 & 1.9 \\
$9-13$ & 1.7 & 1.7 & 1.0 & 0.9 & 0.6 & 0.8 & 0.7 & 0.1 \\
$13-16$ & 2.6 & 2.0 & 1.2 & 2.0 & 1.2 & -0.2 & 0.8 & 0.4 \\
\hline
\end{tabular}

Pulse Rate--Pulse rates after the sixth year show a divergence of means greater than the factor for unreliability, and we are justified in assuming the existence of true differences. The standard deviations do not differ by the amount of the factor, and may be identical. Here again, however, the difference is constantly in one direction.

Pulse Pressure $\times$ Pulse.-Pulse pressure times pulse is a measure, introduced by Erlanger and recently discussed by Wiggers, Addis and others, which may with several important reservations be regarded as a rough measure of cardiac output. Its main value is in estimating output in a given individual under different conditions of strain. In a large series the mean values may have some interest as indicating general tendencies. More than this we are unprepared to say, but we have calculated our data in the same way as for pressures and pulse. It is noteworthy that the pulse pressure-pulse product is practically constant up to the twelfth year and identical for the two sexes. At this time a slight progressive rise occurs which is distinctly greater for girls than 
for boys. Whether this indicates a pre-adolescent or adolescent rise in cardiac output or merely reflects a lessening of peripheral resistance or some other circulatory change incidental to adolescence it is impossible to state with certainty.

TABLE 12.-Boys

\begin{tabular}{|c|c|c|c|c|c|c|c|c|c|c|c|c|}
\hline 兽 & $\stackrel{\infty}{\infty}$ & 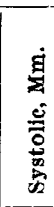 & 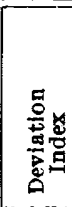 & 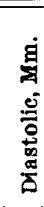 & 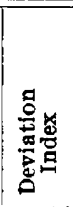 & 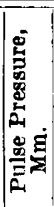 & 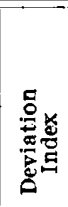 & $\frac{\overrightarrow{\ddot{\vartheta}_{2}}}{\vec{z}}$ & 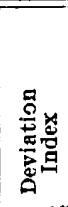 & 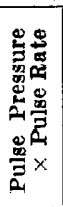 & 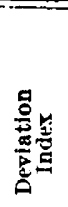 & Remarks \\
\hline 1 & 3 & 102 & +2.4 & 52 & $+1,1$ & 50 & +3.1 & 106 & +0.7 & 5300 & +3.8 & Bronchial asthma, eczema, \\
\hline 2 & 5 & 88 & $\multimap 0.8$ & 66 & +0.5 & 22 & -1.4 & 114 & +1.8 & 2508 & -0.5 & $\begin{array}{l}\text { malnutrition } \\
\text { Convalescent } \text { from pneu- }\end{array}$ \\
\hline 3 & 6 & 100 & +0.9 & 78 & +1.9 & 22 & -1.5 & 120 & +2.4 & 2640 & -0.3 & $\begin{array}{l}\text { monia } \\
\text { Convalescent from pneu- } \\
\text { monia }\end{array}$ \\
\hline 4 & 6 & 110 & +2.5 & 64 & 0.0 & 46 & +2.5 & 138 & +4.0 & 6348 & +5.4 & $\begin{array}{l}\text { Convalegeent from measles } \\
\text { and whooping cough }\end{array}$ \\
\hline 5 & 6 & $\begin{array}{l}76 \\
92\end{array}$ & $\begin{array}{l}-2.8 \\
-0.3\end{array}$ & $\begin{array}{l}56 \\
62\end{array}$ & $\begin{array}{l}+1.1 \\
-0.3\end{array}$ & $\begin{array}{l}20 \\
30\end{array}$ & $\begin{array}{l}-1.8 \\
-0.2\end{array}$ & 100 & +0.7 & 3000 & +0.2 & $\begin{array}{l}\text { 1/27/20: bronchial asthma } \\
3 / 23 / 20 ; \text { same pateint after } \\
7 \text { weeks in country without } \\
\text { attacks }\end{array}$ \\
\hline 6 & 7 & 82 & -2.3 & 60 & +0.1 & 16 & -2.7 & $\cdots$ & $\ldots$ & $\cdots$ & $\ldots .$. & $\begin{array}{l}\text { attacks } \\
\text { Eczema, chronic bronchitis } \\
\text { (asthma?) }\end{array}$ \\
\hline $\begin{array}{l}7 \\
8\end{array}$ & $\begin{array}{l}8 \\
9\end{array}$ & $\begin{array}{l}82 \\
86 \\
86\end{array}$ & $\begin{array}{l}-2.8 \\
-2.3 \\
-2.3\end{array}$ & $\begin{array}{l}72 \\
60 \\
54\end{array}$ & $\begin{array}{l}+0.7 \\
-1.2 \\
-2.2\end{array}$ & $\begin{array}{l}10 \\
26 \\
32\end{array}$ & $\begin{array}{l}-3.8 \\
-1.4 \\
-0.4\end{array}$ & $\begin{array}{l}108 \\
108 \\
108\end{array}$ & $\begin{array}{l}+2.1 \\
+1.9 \\
+2.1\end{array}$ & $\begin{array}{l}1080 \\
2756 \\
3456\end{array}$ & $\begin{array}{l}-3.0 \\
-0.2 \\
+1.0\end{array}$ & $\begin{array}{l}\text { Imbecile; cold, blue hands } \\
3 / 16 / 20 ; \text { bronchial asthma } \\
3 / 23 / 20 ; \text { same patient }\end{array}$ \\
\hline 9 & 9 & 80 & -3.2 & 70 & +0.3 & $\begin{array}{l}32 \\
10\end{array}$ & -0.4 & $\cdots$ & +2.1 & 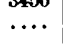 & +1.0 & 1/27/20; bronchial asthma, \\
\hline 10 & 9 & $\begin{array}{r}92 \\
98 \\
96 \\
102\end{array}$ & $\begin{array}{l}-1.4 \\
-0.5 \\
-0.8 \\
+0.1\end{array}$ & $\begin{array}{l}60 \\
84 \\
64 \\
80\end{array}$ & $\begin{array}{r}-1.2 \\
+2.5 \\
+0.6 \\
+1.8\end{array}$ & $\begin{array}{l}32 \\
14 \\
30 \\
22\end{array}$ & $\begin{array}{l}-0.4 \\
-3.6 \\
-0.7 \\
-2.2\end{array}$ & $\begin{array}{r}100 \\
96 \\
90 \\
80\end{array}$ & $\begin{array}{l}+1.3 \\
+0.9 \\
+0.3 \\
-0.7\end{array}$ & $\begin{array}{l}3200 \\
1344 \\
2700 \\
1760\end{array}$ & $\begin{array}{l}+0.6 \\
-2.5 \\
=0.3 \\
-1.8\end{array}$ & $\begin{array}{l}\text { 2/3/20; same patient } \\
2 / 24 / 20 ; \text { same patient } \\
3 / 2 / 20 ; \text { same patient } \\
2 / 17 / 20 ; \text { bronchial astl }\end{array}$ \\
\hline & & & -0.8 & 64 & -0.6 & 32 & 0.4 & 96 & +0.9 & & +0.4 & $\begin{array}{l}\text { no attack for } 3 \text { weeks } \\
3 / 9 / 20 ; \text { same patient; no }\end{array}$ \\
\hline 11 & 9 & 68 & --5.1 & 54 & -2.2 & 14 & -3.6 & .. & & $\cdots$ & & $\begin{array}{l}\text { attack for } 6 \text { weeks } \\
\text { Frequent headaches, pale, } \\
\text { cold hands }\end{array}$ \\
\hline I2 & 10 & 114 & +1.7 & 46 & -3.8 & 68 & 6.2 & 80 & +0.7 & 5440 & +4.4 & $\begin{array}{l}\text { Severe postural defects; } \\
\text { very poor muscular tone; } \\
\text { malnutrition }\end{array}$ \\
\hline $\begin{array}{l}13 \\
14\end{array}$ & $\begin{array}{l}11 \\
12\end{array}$ & $\begin{array}{r}94 \\
120\end{array}$ & $\begin{array}{r}-1.5 \\
+2.2\end{array}$ & $\begin{array}{l}66 \\
74\end{array}$ & $\begin{array}{l}-0.7 \\
+0.6\end{array}$ & $\begin{array}{l}28 \\
46\end{array}$ & $\begin{array}{l}-1.1 \\
+1.4\end{array}$ & $\begin{array}{r}82 \\
116\end{array}$ & $\begin{array}{l}-0.3 \\
+3.3\end{array}$ & 2296 & $\begin{array}{l}-1.1 \\
+3.7\end{array}$ & $\begin{array}{l}\text { Bronchial asthms } \\
\text { "Nervous," pale, mother } \\
\text { luetic }\end{array}$ \\
\hline $\begin{array}{l}15 \\
16\end{array}$ & $\begin{array}{l}13 \\
13\end{array}$ & $\begin{array}{l}90 \\
80 \\
88\end{array}$ & $\begin{array}{l}-2.8 \\
-4.3 \\
-4.3\end{array}$ & $\begin{array}{l}50 \\
48 \\
54\end{array}$ & $\begin{array}{l}-4.4 \\
-4.8 \\
-3.6\end{array}$ & $\begin{array}{l}40 \\
32 \\
88\end{array}$ & $\begin{array}{l}+0.7 \\
-0.7\end{array}$ & 72 & -1.2 & $\begin{array}{l}2304 \\
6336\end{array}$ & $\because \ddot{1.0}$ & $\begin{array}{l}\text { Froelich syndrome, obese } \\
\text { 2/3/20; bronchial astbema }\end{array}$ \\
\hline 17 & 13 & 88 & -3.1 & 80 & $\begin{array}{r}0.6 \\
+1.6\end{array}$ & 8 & -4.7 & 104 & +2.0 & 832 & $\begin{array}{l}+2.0 \\
-3.1\end{array}$ & $\begin{array}{l}\text { Congenital heart disease, } \\
\text { probably pulmonic steno- } \\
\text { sis; decompensation with } \\
\text { extreme cyanosis; died } \\
\text { about } 1 \text { week later }\end{array}$ \\
\hline 18 & 14 & 140 & +4.0 & 58 & -3.1 & 82 & +7.1 & 92 & +1.1 & 7544 & +6.2 & $\begin{array}{l}\text { Vasomotor instability; } \\
\text { blue, cold hands; heart } \\
\text { normal except for power- } \\
\text { ful apex thrust and boom- } \\
\text { ing first sound; urine re } \\
\text { peatedly normal; has col- } \\
\text { lapsed several times after } \\
\text { exercise. }\end{array}$ \\
\hline
\end{tabular}

EFFECTS OF ADOLESCENCE: PERIODIC VARIATIONS

Our graphs show throughout certain fairly constant periodic variations which we are inclined to believe correspond with periods in the development of children. Similar fluctuations occur, it will be recalled, in curves of mean height and weight. Expressed in terms of annual increment, the fluctuations are shown in Table 11. 
Both diastolic and pulse pressures, beginning at about age 9 , show a period of standstill which lasts until about the twelfth year, when the rate of increase is again accelerated. During the corresponding periods the curve for pulse is in the reverse direction, the rate of decrease in

TABLE 12.-GiRLS

\begin{tabular}{|c|c|c|c|c|c|c|c|c|c|c|c|c|}
\hline 总 & 选 & 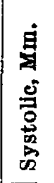 & 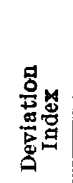 & 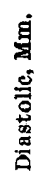 & 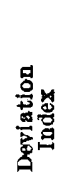 & 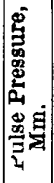 & 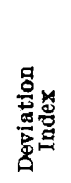 & $\stackrel{\frac{9}{3}}{\vec{\beta}}$ & 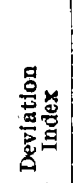 & 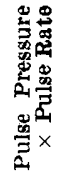 & 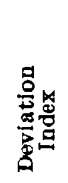 & Remarks \\
\hline 19 & 7 & 62 & -5.0 & 48 & -2.4 & 14 & -3.3 & 84 & -1.1 & 1176 & -2.7 & esis; "nervous" \\
\hline 20 & 10 & $\$ 2$ & -3.0 & 70 & +0.1 & 12 & -3.1 & 106 & +1.3 & 1272 & -2.2 & $\begin{array}{l}\text { speech defect blepharitis; } \\
\text { Eczematous } \\
\text { blue hands; poor muscu- } \\
\text { lar tone }\end{array}$ \\
\hline 21 & 11 & 82 & -3.1 & 66 & -0.8 & 16 & -2.6 & 88 & -0.5 & 1408 & -2.0 & $\begin{array}{l}\text { Vasomotor instability: red- } \\
\text { purplish hands; styes }\end{array}$ \\
\hline 22 & 11 & 112 & +1.1 & 48 & -3.5 & 64 & +4.8 & 120 & +2.5 & 7680 & +5.9 & $\begin{array}{l}\text { purpunsh nanas; styes } \\
\text { vasomotor instability; } \\
\text { mottled hands; well nour }\end{array}$ \\
\hline 23 & 12 & 120 & +2.0 & 70 & -0.3 & 50 & +2.5 & 90 & -0.3 & 4500 & +1.8 & $\begin{array}{l}\text { Frequent colds; tuberculo- } \\
\text { sis (?); anemia }\end{array}$ \\
\hline 24 & 12 & 92 & -2.0 & 60 & -1.7 & 32 & -0.3 & 104 & +1.0 & 3328 & +0.3 & $\begin{array}{l}\text { Bronchial asthma: chronic } \\
\text { medlastinitis: malnutrition }\end{array}$ \\
\hline 25 & 12 & 72 & -4.9 & 60 & -1.7 & 12 & -3.4 & 102 & +0.8 & 1224 & -2.4 & $\begin{array}{l}\text { Chronic general lympha- } \\
\text { denitis; poor vasomotor } \\
\text { tone }\end{array}$ \\
\hline 26 & 13 & 128 & +3.1 & 86 & +1.7 & 42 & +1.0 & 92 & -0.1 & 3864 & +1.0 & $\begin{array}{l}\text { Chron i c endocarditis; } \\
\text { chorea }\end{array}$ \\
\hline 27 & 13 & $\begin{array}{r}102 \\
100 \\
96\end{array}$ & $\begin{array}{l}-0.9 \\
-0.8 \\
\rightarrow 1.8\end{array}$ & $\begin{array}{l}56 \\
56 \\
56\end{array}$ & $\begin{array}{l}-2.3 \\
-2.3 \\
-2.3\end{array}$ & $\begin{array}{l}46 \\
44 \\
40\end{array}$ & $\begin{array}{l}+1.6 \\
+1.3 \\
+0.7\end{array}$ & $\begin{array}{l}124 \\
120 \\
100\end{array}$ & $\begin{array}{l}+3.0 \\
+2.6 \\
+0.8\end{array}$ & $\begin{array}{l}5704 \\
5280 \\
4000\end{array}$ & $\begin{array}{l}+3.1 \\
+2.6 \\
+1.0\end{array}$ & $\begin{array}{l}\text { 2/17/20; chronic endocar- } \\
\text { ditis, mitral insuffeiency } \\
8 / 11 / 20 ; \text { same patient } \\
\text { b/20/20; same patient }\end{array}$ \\
\hline 28 & 14 & 114 & +0.6 & 54 & -2.4 & 60 & +3.3 & 76 & -1.0 & 4524 & +1.8 & $\begin{array}{l}\text { Frequent headaches; palpi- } \\
\text { tation; poor vasomotor } \\
\text { tone } \\
\text { Vasomator instability: }\end{array}$ \\
\hline 30 & 15 & 98 & -2.6 & 66 & -1.0 & 28 & -1.1 & 108 & +1.8 & 3024 & -0.1 & $\begin{array}{l}\text { chilblaing } \\
\text { 1/31/20; mitral insufficiency, } \\
\text { well compensated; poor } \\
\text { vasomotor tone: blue } \\
\text { hands; migraine; periodic } \\
\text { vomiting }\end{array}$ \\
\hline 31 & 16 & $\begin{array}{r}98 \\
118\end{array}$ & $\begin{array}{l}-2.0 \\
+0.4\end{array}$ & $\begin{array}{l}66 \\
96\end{array}$ & $\begin{array}{l}-1.0 \\
+1.7\end{array}$ & $\begin{array}{l}32 \\
22\end{array}$ & $\begin{array}{l}-0.5 \\
-1.7\end{array}$ & $\begin{array}{l}100 \\
124\end{array}$ & $\begin{array}{l}+1.0 \\
+3.0\end{array}$ & $\begin{array}{l}3200 \\
2728\end{array}$ & $\stackrel{+0.1}{-0.4}$ & $\begin{array}{l}2 / 7 / 20 ; \text {;ame patient } \\
2 / 10 / 20 ; \text { chronic endocar- } \\
\text { ditis, mitral stenosis and } \\
\text { insuffeciency; malnutration }\end{array}$ \\
\hline 32 & 15 & $\begin{array}{r}106 \\
88\end{array}$ & $\begin{array}{l}-1.2 \\
-3.4\end{array}$ & $\begin{array}{l}72 \\
62\end{array}$ & $\begin{array}{l}-0.7 \\
-1.5\end{array}$ & $\begin{array}{l}34 \\
16\end{array}$ & $\begin{array}{l}-0.1 \\
-2.7\end{array}$ & $\begin{array}{r}106 \\
82\end{array}$ & $\begin{array}{l}+1.4 \\
-0.5\end{array}$ & $\begin{array}{l}3604 \\
1272\end{array}$ & $\begin{array}{l}+0.9 \\
-2.5\end{array}$ & $\begin{array}{l}3 / 23 / 20 ; \text { same patient } \\
\text { Dysmenorrhea; constipa- } \\
\text { tion; "always tired" }\end{array}$ \\
\hline
\end{tabular}

pulse rate coming to a halt in the case of boys and in the case of girls being replaced by a period of increase; in both, this period is followed by a period of decrease. The changes in the diastolic pressure and pulse pressure are, therefore, balanced by corresponding changes in the pulse rate in the opposite direction and this balance is clearly shown by the relative constancy of the pulse pressure-pulse product.

Such fluctuations are evidence of changes in the circulation incident to bodily development and illustrate the periodic character of development. It is probable that they indicate functional and, perhaps, organic changes in the vessels and in their nervous control, causing various inner readjustments in circulation. In any case it appears that preceding adolescence there is a period of relative inactivity, both in growth and 
in the rapidity of changes in circulatory phenomena, which is followed by a period of acceleration in these various reactions.

STATES OF PATHOLOGIC TENSION

While we have in the main confined ourselves up to the present time, to the study of normal children, we have made a few scattered observations in children suffering with various disorders and the results, shown in Table 12, will serve to illustrate the application of the methods under discussion.

Attention is directed to the rather interesting findings in children with asthma and the fact that in some cases improvement in condition can be followed by a lessening of the deviation index.

It will be recalled that the statement is often made, and can be found in at least one of the important text-books on pediatrics, that the study of blood pressure in children is of little practical importance. So long as sphygmomanometry is only used qualitatively to determine the presence or absence of permanent hypertension, such an assertion may be true in general. Even so, we have seen a few cases in which abnormally high systolic pressure gave us the first "lead" to a diagnosis. In the field of hypotension in children there appears to be much unexplored ground. The vasomotor disorders are among the most significant incidents of childhood, particularly during adolescence in girls and by no other method is their presence so clearly revealed as by diastolic and pulse pressures. In asthma and the allied disorders blood pressure changes certainly have a significance not as yet fully appreciated. In the nephritis of children Gordon, ${ }^{14}$ and Berkley and Lee, ${ }^{15}$ have noted significant alterations in pressure. In severe diarrheas Trumpp ${ }^{16}$ has noted a marked drop in systolic pressure. Rolleston ${ }^{17}$ has noted very subnormal systolic pressures in diphtheria reaching the low point during the second week and gradually returning to normal by the seventh week. He also noted that during convalesence the pressure in the recumbent position was higher than in the erect position. That further observations of blood pressure would give us information of value as to the progress of myocardial degeneration in diphtheria seems to us almost certain; yet Rolleston concludes his paper by saying that the method is of little practical value. If further evidence of the

14. Gordon, L.: The Blood Pressure in Cases of Acute Nephritis of Children, Arch. Pediat. 28:343, 1911.

15. Berkley, H. K., and Lee, J. M.: Hypertension in Nephritis in Childhood, With a Study of Ninety-Three Cases, Am. J. Dis. Child. 13:354 (Apri1) 1917.

16. Trumpp, J.: Blutdruckmessungen an gesunden und kranken Säuglingen, Jahrb. f. Kinderh. 63:43, 1906.

17. Rolleston, J. D.: The Blood Pressure in Diphtheria, Brit. J. Dis. Child. $8: 433,1911$. 
value of blood pressure determinations in children were needed, we might point to the recent paper of Wilson ${ }^{18}$ who used systolic pressures as an index of cardiac fatigue from strain.

Finally, mention should be made of the recent contribution by Alvarez and his associates ${ }^{19}$ in which the systolic pressures of a large group of adults were studied by the frequency method. A comparison of their results with ours is of much interest.

The general usefulness of the method we have discussed may seem to be limited by the apparent difficulties of application. The size and apparent complexity of the tables can hardly be avoided. It is necessary to use Table 11 at least, in applying the method, and we see no other way at present further to simplify it. The effect of age and sex both on averages and on deviation values in childhood is so great that the exact standard figures must be at hand before the index can be determined. As contrasted with the difficulties the advantage of being able to assign to a given reading the place which it occupies in the normal scale and of being able to state in objective terms the degree of normality or of abnormality seems worth some extra effort, especially to the pediatrist who has vainly endeavored to estimate the true significance of his blood pressure findings and very likely has abandoned the measurement of blood pressure in children as of no practical value. We hope we have not made the method look too formidable. In reality its application is very simple. To find the deviation index requires only about 20 seconds, and its significance can be determined by a glance at Table 1 , or can be remembered after a little practice. Because the deviation index itself lacks immediate significance on inspection until one has worked with it for some time, it might be better instead to record the corresponding "chances" or "betting odds," with their striking imaginative appeal, though this would add another step in the process.

We do not wish to set up our standards as in any way definitive or final. We have attempted to express the probable accuracy or reliability in Tables 6-10. When a larger series of normal data has been gathered, a closer approximation to the true or absolute values will be possible. Till then we believe that our standards will suffice for practical purposes to define and analyze the significance of blood pressure findings in chidren, in the hospital, clinic and office, both in individual cases and in the study of series of cases showing functional or anatom-

18. Wilson, M. G.: The Circulatory Reactions to Graduated Exercise in Normal Children, Am. J. Dis. Child. 20:188, 1920.

19. Alvarez, W. C., Wulzen, R., Taylor, F. B. and Starkweather, E.: Blood Pressure in University Freshmen and Office Patients, Arch. Int. Med. 26: $381,1920$. 
ical aberration of the cardiovascular apparatus. By using the method, too, it is possible that more reliable tests of cardiovascular function may be developed.

\section{SUMMARY}

1. Our lack of a proper measure of the normal range of blood pressure and of the relative significance of various deviations from the average normal blood pressure is due to the failure to apply correct methods to the compilation of normal statistics and has made it impossible in practice to obtain the full usefulness inherent in sphygmomanometric methods. Our need is for standards of deviation.

2. Such standards must be based on the statistical method of frequency distribution. In connection with normal averages they can be used in the individual case to determine the relative significance and importance of any deviation from the normal.

3. Normal means and standard deviations for systolic, diastolic and pulse pressures and for pulse and pulse pressure-pulse product have been compiled for boys and girls separately, by year, between the ages of 4 and 16 years.

4. Reference tables for clinical application are given.

5. Mean systolic pressure shows no significant difference between the sexes within the period studied. Mean diastolic and mean pulse pressure do show significant sexual differences. Standard deviations are in practically all cases greater for girls, indicating a normally greater variability in female children, which is particularly marked during adolescence.

6. Illustrative examples of the method of measuring deviations in various pathologic states are given.

7. The frequent occurrence of states of hypotension in children is pointed out, in contrast with the relatively greater frequency of states of hypertension in adults. Note is made of the common occurrence of hypotension in bronchial asthma in children.

8. The method, while involving the use of the reference tables, requires only a few seconds to apply. 